\title{
4. PLIOCENE VOLCANOGENIC SEDIMENTS AND MESOZOIC CHALKS SOUTHEAST OF JAPAN: DSDP SITE 196
}

\author{
The Shipboard Scientific Party ${ }^{1}$
}

\section{SITE DATA}

Occupied: 29 Sept-2 Oct 1971

Position: Abyssal floor east of Izu-Bonin Trench; lat $30^{\circ} 07.0^{\prime} \mathrm{N}$

long $148^{\circ} 34.5^{\prime} \mathrm{E}$

Water Depth: 6184 meters

Number of Cores: 6

Total Penetration: 623 meters

Deepest Unit Recovered: Kimmeridgian to Barremian cherty limestone

Main Results: At this site, the Kimmeridgian to Barremian limestones are over 150 meters thick, and the top of the opaque layer is pre-Cenozoic in age. Basement was not reached, but judging from exceptional seismic reflection profiles, it was a few hundred meters below total depth and must certainly be at least Jurassic in age.

\section{BACKGROUND}

After completing drilling at Sites 194 and 195, the nature and age of the smooth acoustic basement of the northwest Pacific still remained a mystery. None of the eight sites of Leg 6 had penetrated to acoustic basement, although the lower transparent layer had been sampled in subcrop at Sites 49 and 50. Our four holes had penetrated the opaque layer, and three of them had sampled the same Kimmeridgian to Barremian limestones found in the lower transparent layer at Site 50 , but none had reached basement. Although a Late Jurassic to earliest Cretaceous age for the sediments resting on acoustic basement seemed now fairly certain, the nature of the smooth basement remained unknown. To the south and east of Site 195 the upper transparent layer forms a blanket of decreasing thickness over an opaque layer that seems to extend far to the south, unchanged in average thickness or opacity. Since the thin transparent layer posed serious problems for spudding in, it seemed very likely that chances of penetrating the massive cherts would be drastically reduced as the cover thinned. It thus seemed highly desirable to make another assault on basement before the southerly track of

\footnotetext{
${ }^{1}$ Bruce C. Heezen, Lamont-Doherty Geological Observatory; Ian D. MacGregor, University of California, Davis; Helen P. Foreman, Oberlin College; George Forristall, Eidgenössische Technische Hochschule, Zürich; H. Hekel, Queensland Geological Survey, Brisbane; Reinhard Hesse, Technische Hochschule, Munich; Robert H. Hoskins, New Zealand Geological Survey, Lower Hutt; E. John W. Jones, University College, London; Ansis Kaneps, Scripps Institution of Oceanography, La Jolla; Valeri A. Krasheninnikov, Academy of Sciences, Moscow; Hakuyu Okada, Kagoshima University, Japan; Michael H. Ruef, Washington Department of Ecology, Olympia.
}

Leg 20 took the ship into the vast area of the western Pacific where the upper transparent layer is less than 20 meters thick. Consequently, a southerly course was chosen in order to prospect for an attractive site within the area of thicker Neogene sediments which lies east of the Bonin, Japan, and Kuril volcanic arcs. The location of Site 196 and bathymetry are shown in Figures 1 and 2, respectively; seismic reflection profiles on site approach and leaving the site are given in Figures 3 and 4.

\section{OPERATIONS}

After the prospective site was crossed (course, $098^{\circ}$ ), a brief investigation was made of the area. Although the Glomar Challenger's profiler record across the site did not clearly show the deep reflectors anticipated, the site still seemed quite attractive. The upper sediments were sufficiently thick (110 meters) to spud in safely, and the depth of penetration, although the greatest so far attempted, did not appear to exceed the contract limit. On passing over the prospect a second time, the beacon was dropped while underway at 2115 on 29 September 1971. Hole 196 was spudded in at 1115 on 30 September. Bottom contact was sensed on the weight indicator at 6211 meters. The PDR depth of 6194 meters (to drill floor; 6178 to transducer, based on a sounding of $3265 \mathrm{tau}$ ) was adopted as the mud line. The bit was washed down 37.5 meters and Core 1 was cut $(6231.5$ to 6241 meters, see Table 1$)$. This core consisted of soft, ashy, radiolarian clay. The bit was washed down to 104 meters and Core 2 was cut (6298 to 6304 meters) 6 meters until the top of the opaque layer slowed drilling and the bit plugged. The core was pulled before attempting to clear the bit so as not to wash the cored material out of the barrel. It was decided to insert the center bit and drill until the drilling rate indicated a change in formation. Because of the trouble experienced with hole fill and stuck string at all previous sites, it was reluctantly decided to forego coring the opaque layer. An added complication which we became aware of prior to Site 196 was that the mud inventory of 1900 bags would not allow the liberal use of mud, which was moderately successful in improving hole conditions at previous sites. Thus, the propsect was that if hole conditions became poor, we would have to abandon the hole, for unless we were supplied with more mud at sea, we could not afford to use mud at the rate it was consumed at Holes 195A and 195B.

Core 2 recovered only dark brown clay, presumably the basal part of the upper transparent layer. None of the sediment appeared hard and thus it seemed clear that the opaque layer had been reached, but not sampled. The drilling rate slowed, and it took 20 minutes to drill from 6390 to 6391 meters. The torque dropped markedly for the last 10 minutes. Since there seemed to be a marked change 


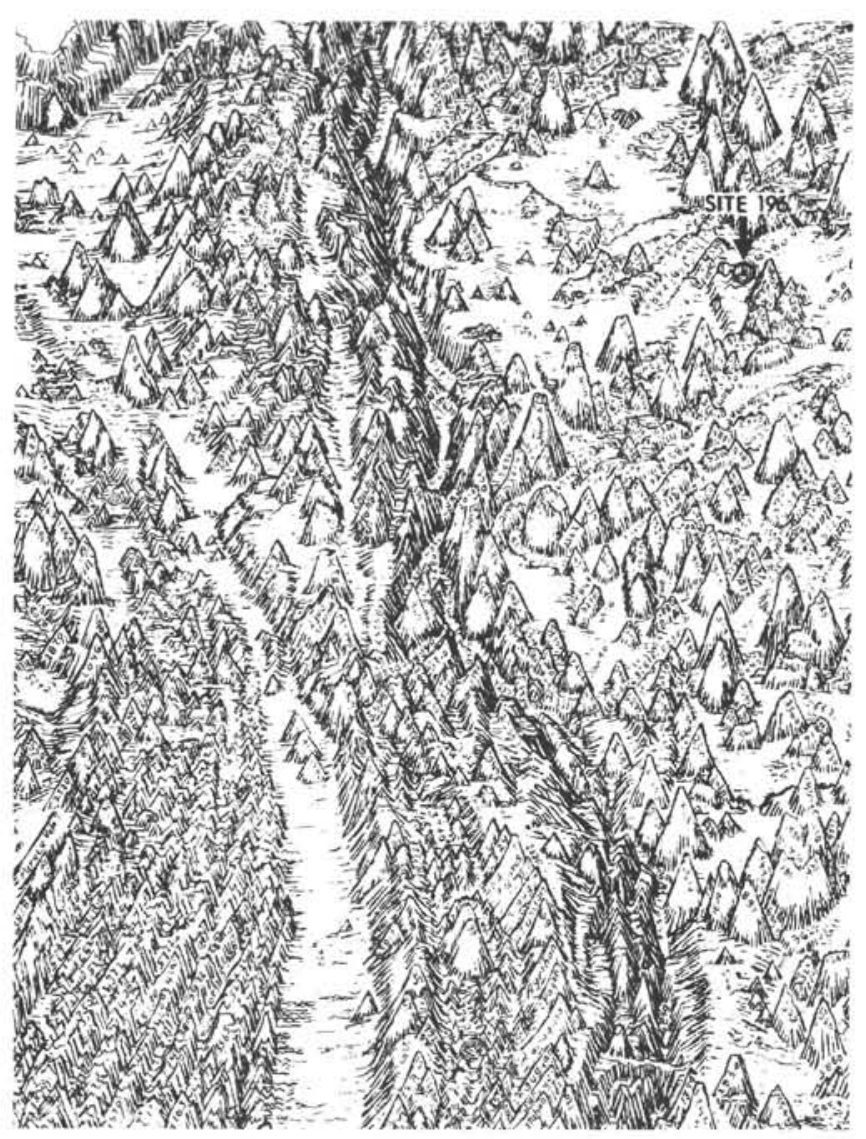

Figure 1. Location of Site 196.

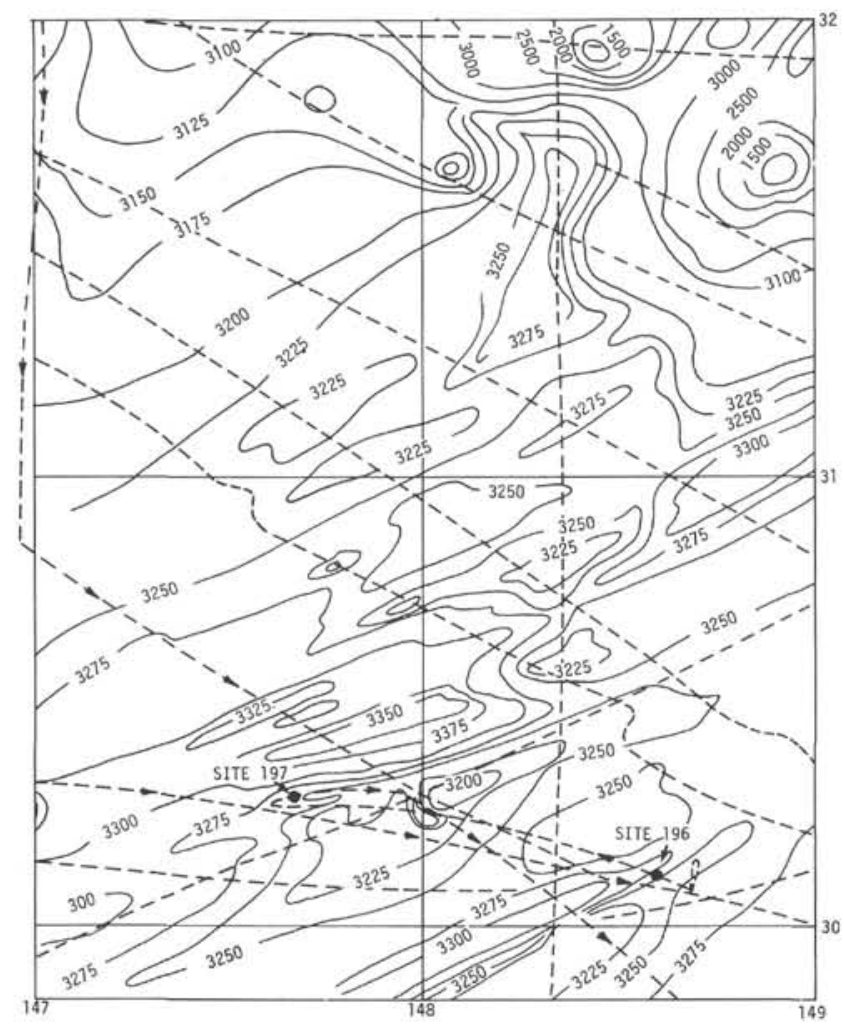

Figure 2. Bathymetry in the vicinity of Site 196.

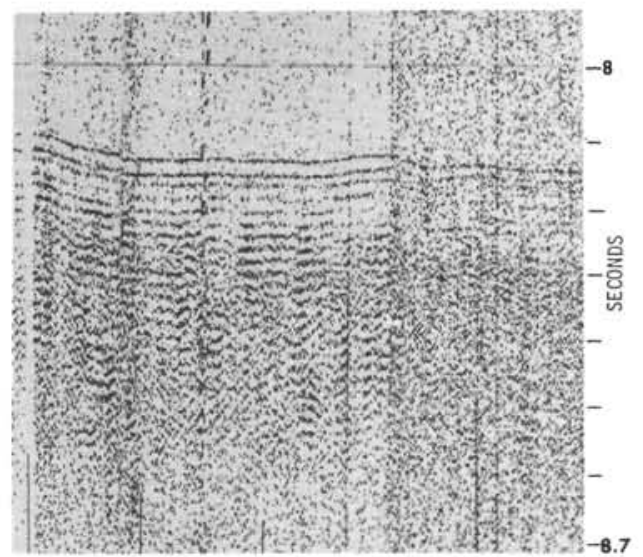

Figure 3. Glomar Challenger profile on Site 196 approach.

in formation, it was decided to cut Core 3 (6391 to 6397 meters).

The bit broke through the hard layer while cutting the core. The core consisted of massive vitreous chert, finegrained sandstone, and dense limestone. The center bit was sent down and the formation was drilled rapidly for 100 meters without filling in of the hole or much resistance. A few hard layers were encountered (presumably chert), but they constituted very little of the section. Core 3 contained the same nannofossil assemblage as was found at Hole 195B and Site 51 , so Core 4 (6494.5 to 6504 meters) was cut in the hope that the string had penetrated deep enough in the section that an older fossil assemblage could be sampled and identified.

After Core 5 (6554.5 to 6562.5 meters) was cut and retrieved, the bit plugged and the string stuck. In a few minutes the bit cleared and after 20 minutes working up and down, the string freed just prior to the arrival of a 25 barrel spot of mud at bottom. The hole was conditioned and it was decided to drill ahead for a substantial distance before attempting to core again. However, the string stuck only 17 meters below the depth of Core 5 and it was decided to pull the center bit and core once more.

In attempting to cut Core 6 (6570 to 6571 meters), the torque drastically increased, and after repeated attempts, only about 1 meter of penetration was gained. The drillers considered that the bit had failed and that presumably a cone had been lost from the four-cone bit. The hole was abandoned and the bit brought up to mud line before the core was retrieved. The core consisted of mixed chips of chert, hole cuttings, and surface red muds which were picked up as the drill bit stabbed into the side of the upper hole or into the sea floor near the hole as the bit hung near mud line while the core barrel was being retrieved. As the string was coming out of the hole and with one joint partly unscrewed, the elevator which was holding that joint at the rig floor failed, scattering broken bits of the latch over the rig floor and letting the entire string drop 1.5 feet until the elevator attached to the traveling block took the load. The 


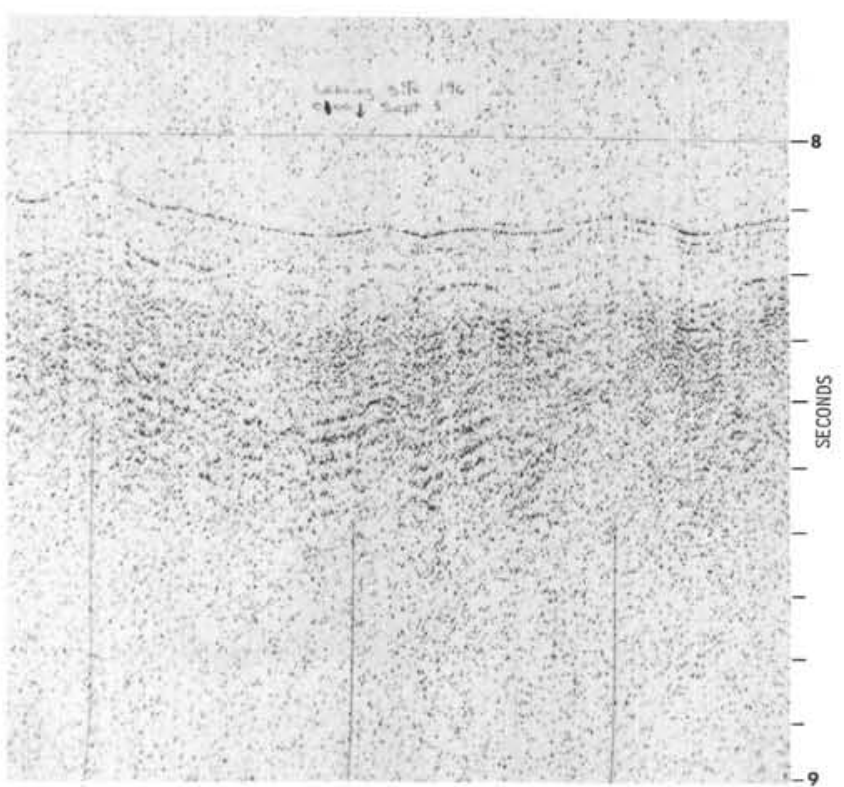

Figure 4. Glomar Challenger seismic profile leaving Site 196.

threads at the partly unscrewed junction held the approximately 500,000-pound load, but were damaged. Had the table rotated one or two more turns before the elevator failed, the entire string would have been lost. The remaining good 250-ton elevator and the destroyed elevator were replaced by the remaining set of 350 -ton elevators.

The bit came to the surface at 2215 on 2 October. It was completely worn out. The cones were nearly stripped of inserts and smoothly polished. The bearing ends were open and the roller bearings were worn thin and partly missing. There appeared to be no point in further attempts at drilling section encountered at Site 196, for it could be anticipated that the bit would again wear out long before the deepest sediment horizons were reached.

The hole was drilled with less pump pressure and only two spots of mud-conditions which may have contributed to the decreased bit life at this hole as compared to the early holes of Leg 20 .

\section{NATURE OF THE SEDIMENTS}

A variety of sediments was encountered in this hole. Brown silty clay and brown and reddish yellow zeolitic clays were obtained in the upper 110 meters of the succession (Cores 1 and 2). Below 190 meters only lithified material was recovered, consisting of radiolarian-rich mudstones and siltstone, chalk, siliceous limestone, and chert (Cores 3, 4, and 5). The deepest core (5) sampled a dark radiolarian-rich siltstone and chert. The section at Site 196 is shown in Figure 5, and correlation with the acoustic stratigraphy at the site and drilling record in Figure 6.

Drilling operations greatly disturbed the cored sequences. Much of Core 2 is made up of lumps of a stiff brown clay embedded in a soft matrix of brown clay somewhat lighter in color. Severe distortion is also evident where the reddish yellow clay is interbedded with the brown clay. Core recovery below 190 meters was poor, amounting to approximately 0.5 meters in Core $3,10 \mathrm{~cm}$ in Core 4 , and only a few small pieces of rock in the core catcher of Core 5.

\section{Core 1 (37.5-47 meters)}

A sticky brown silty clay with traces of Quaternary Radiolaria. Small patches of yellowish brown and grayish clayey vitric ash, lacking microfossils, are present together with several pieces of whitish and dark-colored pumice up to $5 \times 4 \times 3 \mathrm{~cm}$ in size.

\section{Core 2 (104-110 meters)}

Stiff, dark brown zeolitic clay of Campanian age is interbedded with a less-abundant reddish yellow, zeolitic clay. The upper $50 \mathrm{~cm}$ of the sequence is gaseous. The dark brown color of the clay is a result of the relatively high content of manganese micronodules and iron oxides. The

TABLE 1

Coring Summary, Hole 196

\begin{tabular}{|c|c|c|c|c|c|c|c|c|c|c|c|}
\hline \multirow[b]{2}{*}{ Core } & \multirow{2}{*}{$\begin{array}{l}\text { Date } \\
\text { (Sep) }\end{array}$} & \multirow[b]{2}{*}{ Time } & \multicolumn{2}{|c|}{$\begin{array}{l}\text { Subbottom } \\
\text { Depth }(\mathrm{m})\end{array}$} & \multicolumn{2}{|c|}{ Total Depth (m) } & \multirow{2}{*}{$\begin{array}{c}\text { Cored } \\
(\mathrm{m})\end{array}$} & \multirow[b]{2}{*}{ Recovered } & \multirow[b]{2}{*}{ Age } & \multirow[b]{2}{*}{ Lithology } & \multirow[b]{2}{*}{ Paleontology } \\
\hline & & & Top & Bottom & Top & Bottom & & & & & \\
\hline 1 & 30 & 1455 & 37.5 & 47.0 & 6231.5 & 6241.0 & 9.5 & $1 \mathrm{~m}$ & Quaternary & Palagonitic silty red clay & Radiolaria \\
\hline 2 & 30 & 1815 & 104.0 & 110.0 & 6298.0 & 6304.0 & 6.0 & $6 \mathrm{~m}$ & $\begin{array}{l}\text { Late } \\
\text { Cretaceous }\end{array}$ & Zeolitic red clay & Radiolaria \\
\hline 3 & 1 & 0245 & 197.0 & 203.0 & 6391.0 & 6397.0 & 6.0 & $1 \mathrm{~m}$ & $\begin{array}{l}\text { Valanginian- } \\
\text { E. Hauterivian }\end{array}$ & $\begin{array}{l}\text { Limestone/chert/ } \\
\text { siltstone }\end{array}$ & Nannofossils \\
\hline 4 & 1 & 0830 & 300.5 & 310.0 & 6494.5 & 6504.0 & 9.5 & $0.5 \mathrm{~m}$ & $\begin{array}{l}\text { Valanginian- } \\
\text { E. Hauterivian }\end{array}$ & Limestone/chert & Nannofossils \\
\hline 5 & 1 & 1510 & 360.5 & 368.5 & 6554.5 & 6562.5 & 8.0 & Chips & $\begin{array}{l}\text { E. Cretaceous- } \\
\text { ?L. Jurassic }\end{array}$ & Siltstone/chert & Radiolaria \\
\hline 6 & 2 & 0215 & 376.0 & 377.0 & 6570.0 & 6571.0 & 1.0 & Chips & $\begin{array}{l}\text { Chert and lime } \\
\text { red clay from } t\end{array}$ & $\begin{array}{l}\text { one cuttings from bottom } \\
\text { p of hole }\end{array}$ & of hole and \\
\hline
\end{tabular}

Note: Mud line is at 6194 meters. 


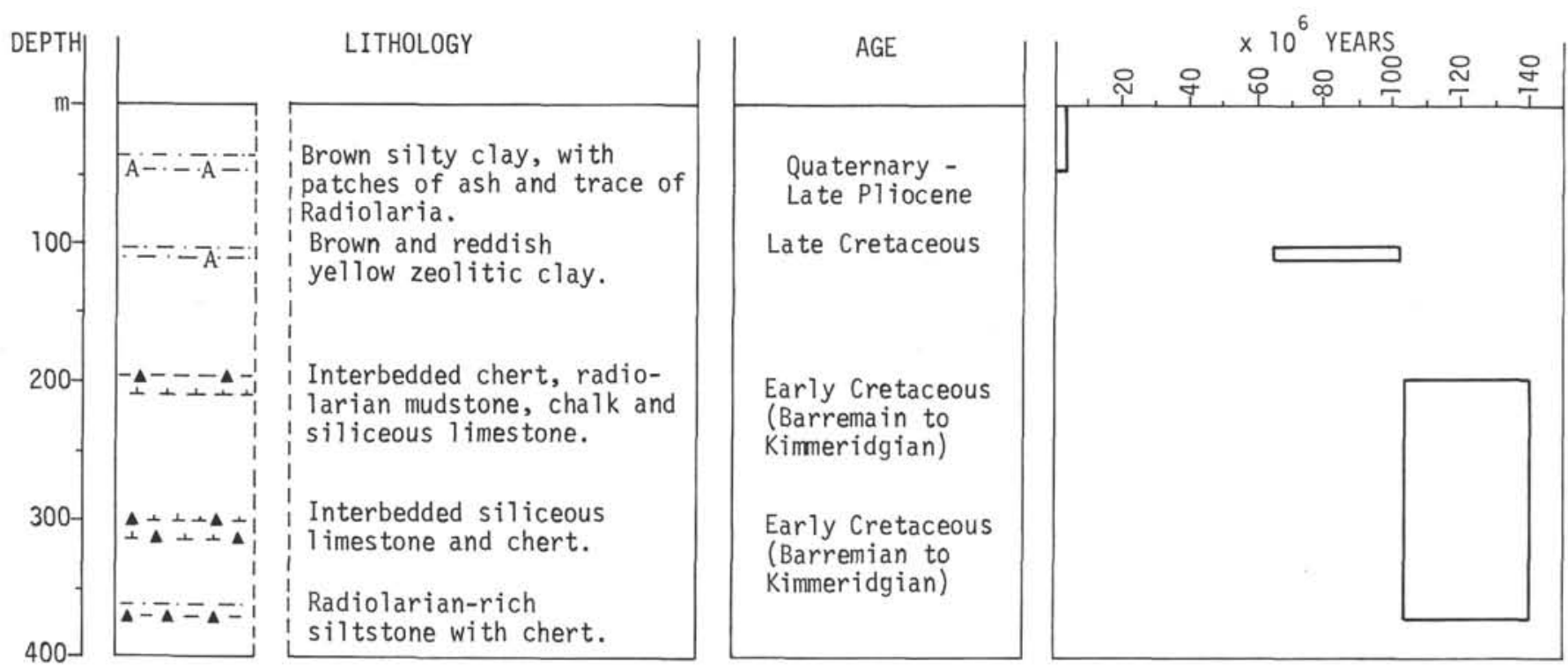

Figure 5. Stratigraphy of Site 196.

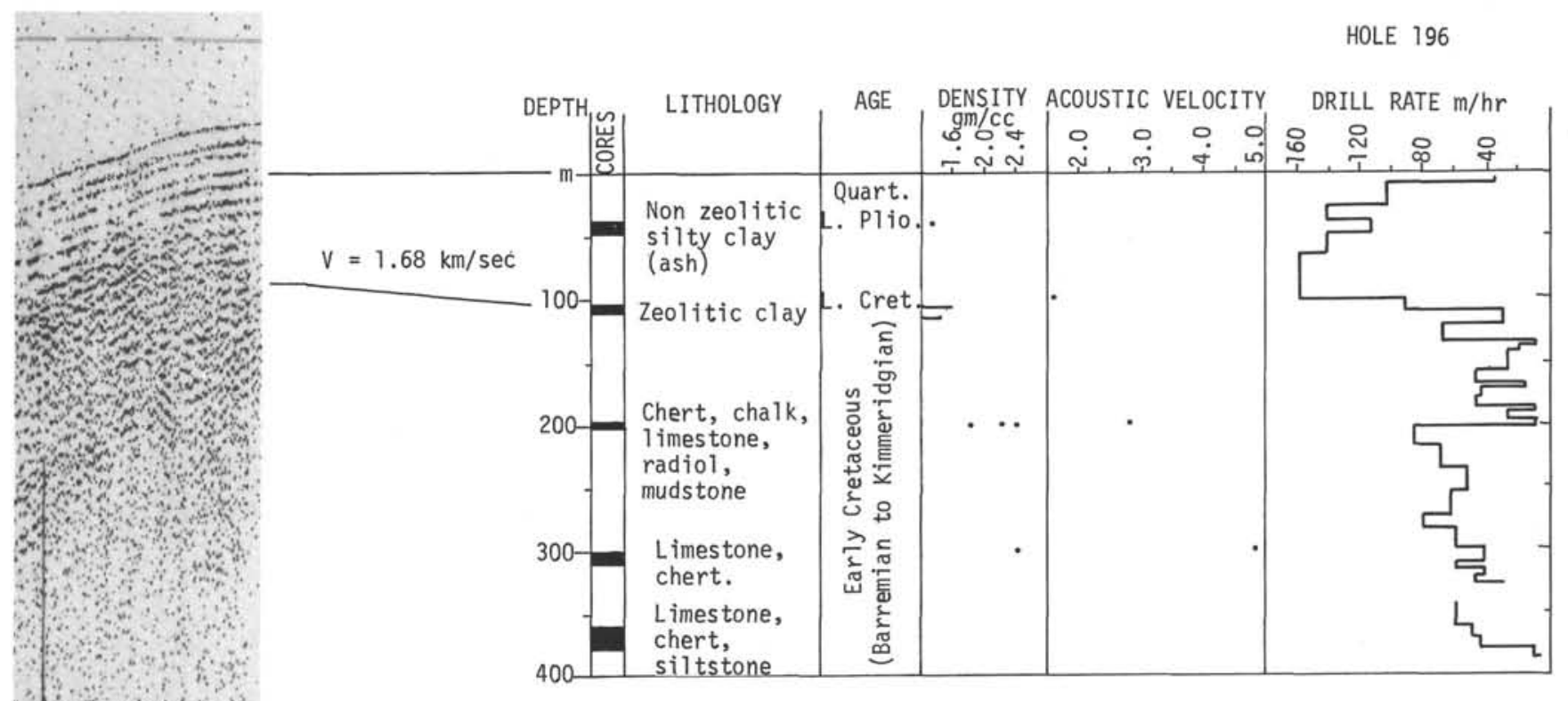


reddish yellow clay contains appreciably less manganese and iron oxides. Only one band of volcanic ash ( $1 \mathrm{~cm}$ thick) was identified.

\section{Core 3 (197-203 meters)}

Dusky red, reddish brown to reddish black cherts occur interbedded with radiolarian mudstone, chalk, and siliceous limestone. The white chalk is an almost pure, partially recrystallized, indurated nannoplankton ooze of early Hauterivian to Valanginian age. Chalk is also found as a thin surface layer on several piecs of chert, where the chertchalk contact is clearly a replacement. In one specimen, for example, a small fragment of chalk enclosed in dark red chert lies $0.5 \mathrm{~cm}$ from the contact. The radiolarian mudstones are pale brown or pale yellow in color and are finely laminated, individual laminae being generally less than $1 \mathrm{~mm}$ thick. One piece of siltstone contains two distinct series of laminae giving one half of the specimen a lighter appearance than the other. The hard porcellanous siliceous limestone is light brownish gray to light gray in color and possesses fine laminations when examined under the microscope.

\section{Core 4 (300.5-310 meters)}

This short core contains a hard, light bluish gray to greenish gray porcellanous siliceous limestone of early Hauterivian to Valanginian age. Gray chert appears to be intimately associated with this limestone as the latter is found as a layer on one of the chert pieces recovered in the core catcher. Chalk, similar to that found in Core 3 , is also part of the sequence in this portion of the hole as it, also, was found attached to a piece of chert in the core catcher.

\section{Core 5 (360.5-368.5 meters)}

A friable, dark-colored, radiolarian-rich laminated siltstone, of Early Cretaceous-? Late Jurassic age, as well as a dark-colored radiolarian-bearing claystone, was recovered in this core and is associated with black and dark gray chert.

\section{Core 6 (376,0-377.0 meters)}

A mixture of brown clay and chert chips was obtained. The depth of recovery is unknown.

\section{BIOSTRATIGRAPHIC SUMMARY}

Radiolaria are present in all of the six cores recovered from this site. Nannofossils are found in Cores 3, 4, and 6, and foraminifera in Core 2 only.

\section{Cenozoic Radiolaria}

Radiolaria are few and well preserved in Core 1 (at 37.5-47 meters below the sediment surface). Of the species listed by Hays (1970) in his zonation of the north Pacific Pleistocene and Pliocene, those listed by Nigrini (1971) in her zonation of the Quaternary of the equatorial Pacific, and those listed or illustrated by Riedel and Sanfilippo $(1970,1971)$ in their zonation of the Pleistocene and Pliocene of the tropical Atlantic and Pacific, only two species, Eucyrtidium tumidulum Bailey, 1856 (= Artostrobium miralestense (Campbell and Clark)) and Lithopera bacca were recognized. Both range from Recent to midMiocene. The presence of $E$. tumidulum subsequent to the extinction of $S$. universus is defined as the $E$. tumidulum Zone. This zone spans the last 400,000 years and is, according to Hays (1970), equivalent to $\Omega$ Zone of Hays (1965) and N.23 of Blow (1969). However, because of the absence of cooccurring restricted Quaternary forms, except one specimen of an oblong form of Spongaster tetras (a cool water form of Spongaster tetras tetras) and because of the depth of the sample ( 37.5 meters below the sediment surface), it is not considered likely that this sample belongs to the E. tumidulum Zone, and it is tentatively identified only as Quaternary.

Core 6 (at a total depth of 6571 meters) contains red clay from near the top of the hole and chips of chert and limestone from the bottom of the hole. The contaminant red clay contains an abundant, well-preserved Quaternary radiolarian fauna.

\section{Cretaceous Radiolaria}

Cores 2 through 6 from 104 to 370 meters below the sediment surface contain rare poor to common, moderately well preserved Radiolaria. Three distinct assemblages could be recognized.

In Core 2 (104-110 meters below the sediment surface) Radiolaria are lacking in Sections 1 and 2 . They are poorly preserved and rare to few in Sections 3, 5, 6, and core catcher, and poorly preserved and common in Section 4. The presence of Dictyomitra torquata, total range not established but known from a number of Campanian localities, suggests a similar age for this fauna. In addition the presence of a number of specimens similar to Dictyomitra sp. (Foreman 1971, pl. 3, fig. 5) and Rhopalosyringium sp. (Foreman 1971, pl. 3, fig. 9), both also known from Campanian localities, tends to confirm this age assignment.

Samples 3-1 pieces 1, 2, and 3, and 4-1 piece 3 (197-203 and 300.5-310 meters below the sediment surface, respectively) contain common, moderately well preserved Radiolaria. The assemblages in these two cores are similar. They contain many of the species found in the 195A-1 bit sample and 195B-1, CC and 2, CC and are considered to belong to the Sethocapsa trachyostraca assemblage. The samples from Cores 3 and 4 particularly have many elements in common with an assemblage described by Fischli (1916) from flint of a molasse conglomerate of the Rigi in Switzerland, considered by him to be of probable Lower Cretaceous age. They also contain some of the species illustrated by Pessagno (1969) from DSDP 1-5A-7-11: Spongosaturnalis dicranacanthos = Acanthocircus dizonius Rüst (?); Spumellariinid (pl. 4, fig. N) = Acaeniotyle bilumaria; and undescribed Spumellariinid (pl. 4, fig. D) $=$ member of Sphaerostylus lanceola group, considered to be Upper Jurassic (Tithonian) on the basis of nannofossils (Bukry and Bramlette, 1969). However, a reevaluation of the nannofossil assemblage by Worsley (1971) suggests that the sample is Berriasian to Valanginian. On the basis of the nannofossils of Leg 20,196-3-1 pieces 1, 2, and 3, and 196-4-1 piece 3 , are considered to be Valanginian to early Hauterivian. 
Sample 5, CC (360.5-370 meters below the sediment surface) contains some of the forms observed in 195A-1 bit sample, 195B-1, 195B-2, 196-3, and 196-4, and in addition some species (Triactoma tithonianum, Emiluvia pessagnoi, and an unusually large form Sethocapsa cetia) were restricted to this sample. Sample 196-5, CC contains the oldest Radiolaria recovered on Leg 20, belonging to the Sethocapsa cetia assemblage which distinguishes it easily from the Sethocapsa trachyostraca assemblage of Cores 196-3 and 196-4, and is considered to be Early Cretaceous-?Late Jurassic in age.

Sample 6, CC contains, besides the contaminated Quaternary radiolarian fauna from the top of the hole, contaminated Mesozoic Radiolaria from above Sample 196-5, CC.

Thus, at Site 196 three distinct Cretaceous radiolarian assemblages can be recognized: 196-2, Late Cretaceous (Campanian); 196-3 and 196-4, Early Cretaceous (Valanginian-early Hauterivian according to nannofossils) Sethocapsa trachyostraca assemblage; and 196-5, Early Cretaceous-?Late Jurassic Sethocapsa cetia assemblage.

\section{Cretaceous Nannofossils}

Nannofossils were recovered from three Early Cretaceous samples-196-3, CC, 196-4, CC, and 196-6, CB. As at Site 195, no distinction could be made among these samples on the basis of nannofossils. Sample 196-6, CB contained contaminated nannofossils of the same age as Samples 196-3, CC and 196-4, CC. The assemblages are comparatively poor, showing fair to strong overcalcification. Stratigraphically significant species which occur throughout and which restrict the age from Valanginian to early Hauterivian according to Thierstein (1971) are Cretarhabdus crenulatus (sensu Thierstein), Markalius circumradiatus, and Cruciellipsis cuvillieri.

\section{Cretaceous Foraminifera}

Zeolitic and zeolitic-limonitic clays of Core 2 (all sections) contain very peculiar assemblages of benthonic foraminifera including only agglutinated (siliceous) species of general Haplophragmoides, Labrospira, Plectorecurvoides, Praecystammina, Paratrochamminoides, Bolivinopsis, Pseudobolivina, Ammodiscus, Glomospira, and Hormoisina. Almost all species are characterized by small sizes of tests (usually less than $0.30 \mathrm{~mm}$ ) with extremely thin homogeneous walls that indicate deep-water conditions of sedimentation. New species greatly predominate among agglutinated foraminifera and exact age determination is hardly possible (tentatively Upper Cretaceous, Campanian to Santonian). This unique assemblage is described in a separate chapter of this report.

Biogenic components found in Site 196 cores are as follows:

\section{Core 1:}

Foraminifera: none.

Nannofossils: none.

Radiolaria: Few well-preserved Radiolaria are present. No stratigraphically restricted forms are recognized except an oblong form of Spongaster tetras considered to be a cool water form of S. tetras tetras, and the core is tentatively regarded as Quaternary. Also present are Lithopera bacca and Eucyrtidium tumidulum.

\section{Core 2:}

Foraminifera: Many samples of Sections 1-6 contain assemblages of very peculiar, small, thin-walled agglutinated (siliceous) foraminifera-various species (mainly new ones) of Haplophragmoides, Labrospira, Plectorecurvoides, Bolivinopsis, Pseudobolivina, Praecystammina, Paratrochamminoides, Ammodiscus, Glomospira. Tentative age: Campanian to Santonian.

Nannofossils: none.

Radiolaria: No Radiolaria in Sections 1 and 2. Poor, rare to common in the remainder of the core. Dictyomitra torquata and associated unnamed species indicate a Campanian age.

Core 3:

Foraminifera: none.

Nannofossils: Stratigraphically important species are "Cretarhabdus crenulatus" (sensu Thierstein), Cruciellipsis cuvillieri, and Markalius circumradiatus of Valanginian to early Hauterivian age.

Radiolaria: Present are Sethocapsa trachyostraca, Staurosphaera septemporata, Acanthocircus dizonius(?), and Syringocapsa agolarium, indicating the Sethocapsa trachyostraca assemblage.

\section{Core 4:}

Foraminifera: none.

Nannofossils: Stratigraphically important species are Cruciellipsis cuvillieri and Markalius circumradiatus of Valanginian to early Hauterivian age.

Radiolaria: Present are Sethocapsa trachyostraca, Staurosphaera septemporata, Acanthocircus dizonius(?), and Syringocapsa agolarium, indicating the Sethocapsa trachyostraca assemblage.

\section{Core 5:}

Foraminifera: none.

Nannofossils: none.

Radiolaria: Present are Triactoma tithonianum, Sethocapsa cetia, Emiluvia pessagnoi, and Dictyomitra cosmoconica, indicating the Sethocapsa cetia assemblage.

\section{PHYSICAL PROPERTIES}

Measurements of bulk density and sonic velocity for Site 196 samples are shown in Figure 7.

Because recovery was quite poor, the data points are few and scattered, and it is difficult to come to any general conclusions other than that the sediment at the site consists of low-density oozes overlying bands of chert, mudstone, and limestone of moderate densities. The depths of transition cannot be accurately placed.

Velocities in the oozes are low, on the order of those in seawater; and velocities in the limestones and cherts are rather high. One sample of limestone was measured to have a slight acoustic orthotropicity; other samples were isotropic or only measured in one direction.

The sample taken from the bottom of Core $2 \mathrm{had}$ a slightly higher velocity than the material above it in the barrel. This is probably due to artificial compaction, as the material collected was quite disturbed by the drilling. If the 


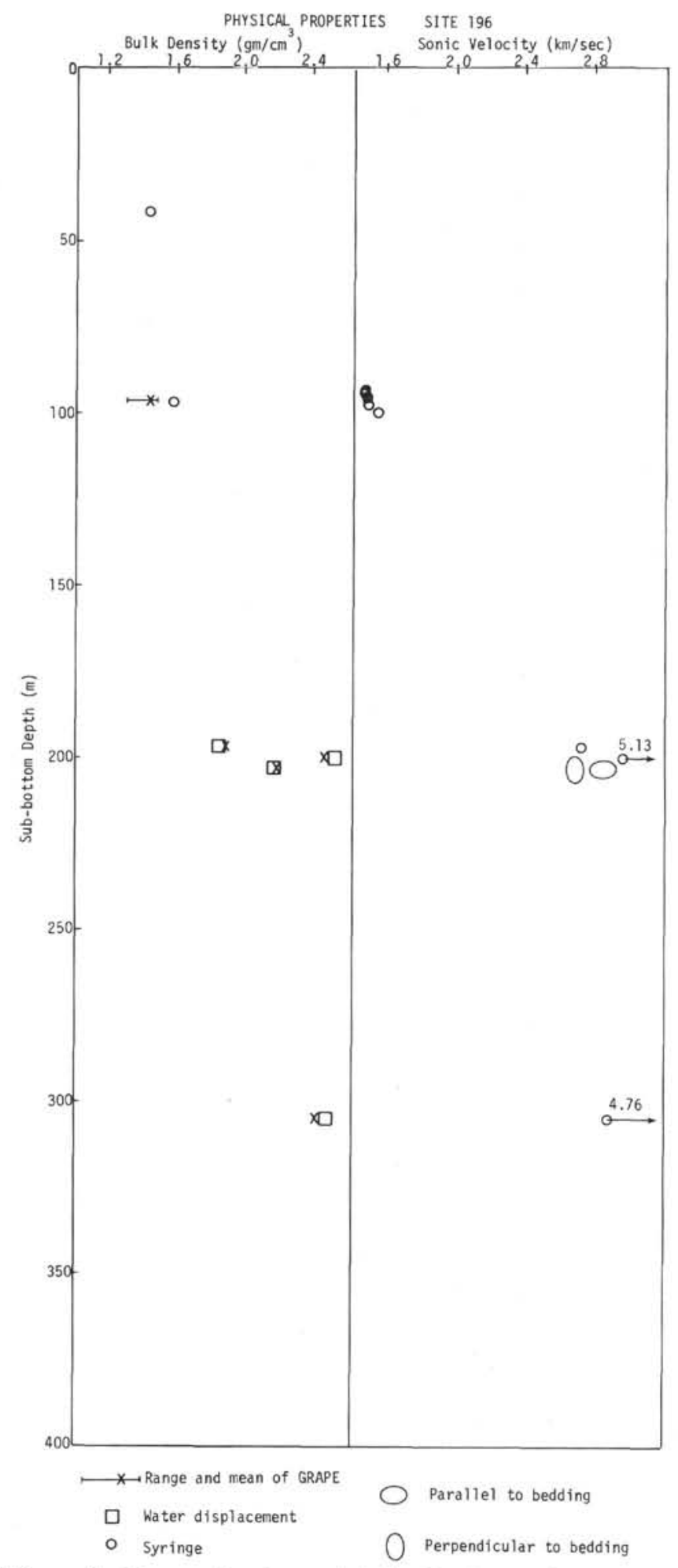

Figure 7. Measured values of bulk density and compressional sonic velocity vs. depth below sea floor at Site 196.

velocities measured in the limestone and mudstone collected from the opaque layer (about $2.7 \mathrm{~km} / \mathrm{sec}$ ) are at all representative of velocities in this layer, then the profile record would indicate this layer to be over 400 meters thick at this location.

\section{CONCLUSIONS}

Site 196 lies southeast of Site 195 and about $200 \mathrm{~km}$ further from the arcs of the western Pacific. This increase in distance of $200 \mathrm{~km}$ is accompanied by a marked decrease in thickness of the wedge of nonzeolitic clays, which decrease by 100 meters from approximately 150 meters at Sites 194 and 195 to 50 meters at Site 196. Although they were not sampled, the thickness available in the hole between the late Pliocene and the Late Cretaceous would accommodate a reasonable 30 to 50 meters of middle and early Tertiary clays. Although the total thickness of the nonzeolitic clays dropped by approximately 100 meters between Sites 195 and 196, the inferred thickness of the Quaternary deposits is only slightly less. Thus, we may infer that the base of the ashy nonzeolitic clays lies in Pliocene sediments at Site 196 and that the underlying abyssal clay layer is relatively the same thickness at Sites 195 and 196, whereas at Sites 194 and 195 it is difficult to distinguish between a plate tectonic convergence of the volcanic sources and the sites of deposition on the one hand and a late Tertiary episode of volcanism on the other. When the probable younger age of the base of the ashy layer at Site 196 is considered, the plate convergence model becomes more attractive. If the crust under Site 196 formerly lay more than $1500 \mathrm{~km}$ from the source under the exceedingly slow deposition regime of the abyssal midoceanic midlatitude desert region and then was transported westward toward the volcanic sources, only arriving at the proximity of their influence in the Pliocene, the transgressive age at the base of the upper ashy layer could be adequately explained. However, this need not be the only explanation, for a progressive shift in active volcanism from north to south along the Japan-Bonin Arc could produce a similar result.

As was the case at each site drilled in the northwest Pacific, the top of the opaque layer is marked by cherts; the age of the top of the cherts is at least as old as Late Cretaceous on the basis of the overlying clays, but applying a reasonable sedimentation rate to the underlying chalks, it can perhaps be inferred that the top of the chert-chalk sequence is Early late or Late early Cretaceous in age. The bit wore out before basement was reached, and if the seismic reflection record obtained by ARIES VII cruise is accepted, then at least 500 meters of sediment lie beneath the Late Jurassic to Early Cretaceous chalk and limestone sequences in which the hole bottomed. However, even with better bits, more time, and ideal weather, acoustic basement could not have been reached at this deepest and oldest site, for the calculated depth of 7500 meters for the smooth reflector exceeds the contract limit and probably the engineering limit set for the present equipment of Glomar Challenger.

Site 196, which was beneath 6194 meters of water and penetrated 377 meters of sediment to a total depth of 6571 meters, was the deepest hole ever drilled anywhere in the ocean. At this site, the oldest sediment sampled from the deep Pacific was obtained and yet, according to the ARIES VII records, a thick, and perhaps long record of earlier Pacific events is contained in the unsampled sequence of beds which lies still deeper beneath the deepest hole. 


\section{REFERENCES}

Blow, W. H., 1969. Late Middle Eocene to Recent planktonic foraminiferal biostratigraphy. Intern. Conf. Planktonic Microfossils, 1st Proc.: Leiden (E. J. Brill), v. 1, p. $199-422$.

Bukry, D. and Bramlette, M. N., 1969. Coccolith age determinations Leg 1 deep sea drilling project: In Ewing, W. M., Worzel, J. L., et al., Initial Reports of the Deep Sea Drilling Project, Volume I: Washington (U.S. Government Printing Office), p. 369-387.

Fischli, H., 1916. Beitrag zur Kenntnis der fossilen Radiolarien in der Riginagelfluh: Naturw. Gesell. Winterthur, Mitt., no. 11, p. 44-47.

Foreman, H. P., 1971. Cretaceous Radiolaria, Leg 7, DSDP. In Winterer, E. L. et al., Initial Reports of the Deep Sea Drilling Project, Volume VII: Washington (U. S. Government Printing Office), p. 1673-1693.

Hays, J. D., 1965. Radiolaria and Late Tertiary and Quaternary history of Antarctic seas. In Biology of the Antarctic Seas, vol. 2: Antarctic Res. Ser. 5, Washington (Am. Geophys. Union), p. 125-184.

1970. Stratigraphy and evolutionary trends of Radiolaria in north Pacific deep-sea sediments: Geol. Soc. Am. Mem., v. 126, p. 185-218.
Nigrini, C. A., 1971. Radiolarian zones in the Quaternary of the equatorial Pacific Ocean. Funnell, B. M. and Riedel, W. R. (Eds.), Micropaleontology of the oceans: Cambridge (Cambridge Univ. Press), p. 443-461.

Pessagno, E. A., Jr., 1969. Mesozoic planktonic foraminifera and Radiolaria. In Ewing, Maurice, et al., Initial Reports of the Deep Sea Drilling Project, Volume I: Washington (U.S. Government Printing Office), p. 607-621.

Riedel, W. R. and Sanfilippo, A., 1970. Radiolaria, Leg 4 , deep sea drilling project. In Bader, R. G., Gerard, R. D., et al., Initial Reports of the Deep Sea Drilling Project, Volume IV: Washington (U.S. Government Printing Office), p. 503-575. 1971. Cenozoic Radiolaria from the western tropical Pacific, Leg 7. In Winterer, E. L. et al., Initial Reports of the Deep Sea Drilling Project, Volume VII: Washington (U.S. Government Printing Office), p. 1529-1672.

Thierstein, H. R., 1971. Tentative Lower Cretaceous calcareous Nannoplankton zonation: Ecol. Geol. Helv., v. 64 , p. $459-488$.

Worsley, T. R., 1971. Calcareous nannofossil zonation of Upper Jurassic and Lower Cretaceous sediments from the western Atlantic: Plankt. Conf., 2nd, Rome Proc., v. 2, p. 1301-1322.

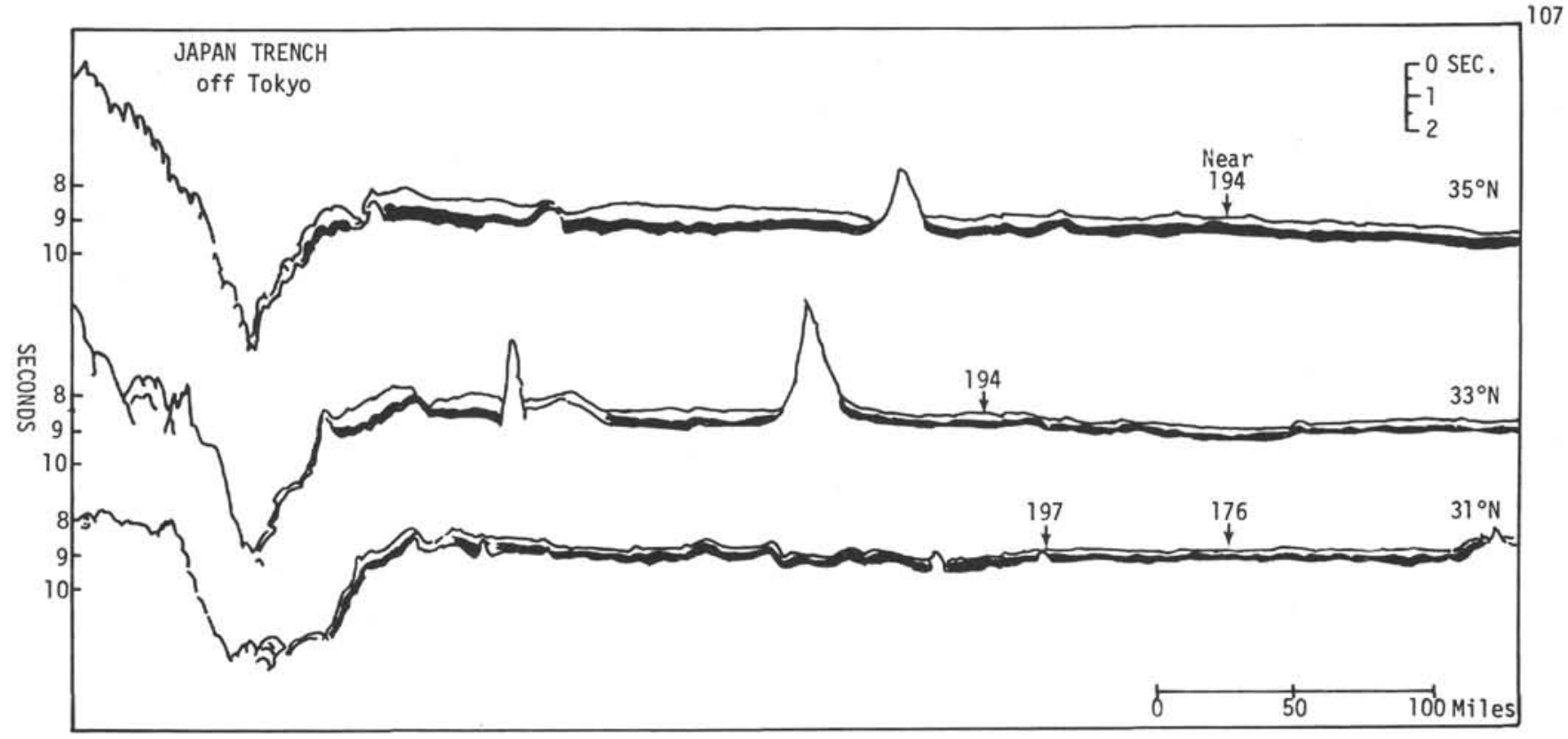

$\neg=\begin{aligned} & \text { Upper Transparent Layer } \\ & \text { Opaque Layer }\end{aligned}$

Figure 8. The upper transparent layer thins from west to east with increasing distance from the volcanoes of the Asiatic Arcs. Location of Sites 194-197 indicated on three seismic reflection profiles. 


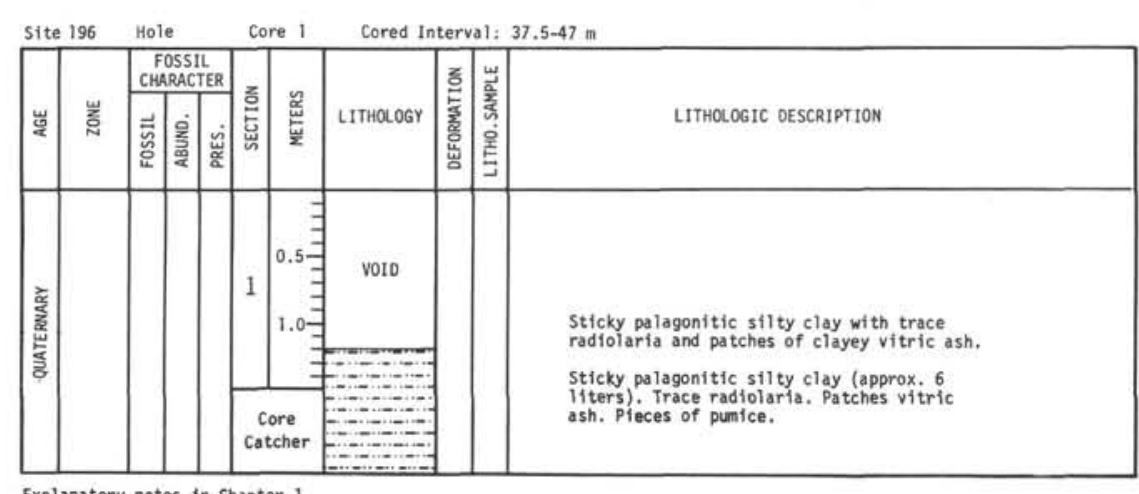

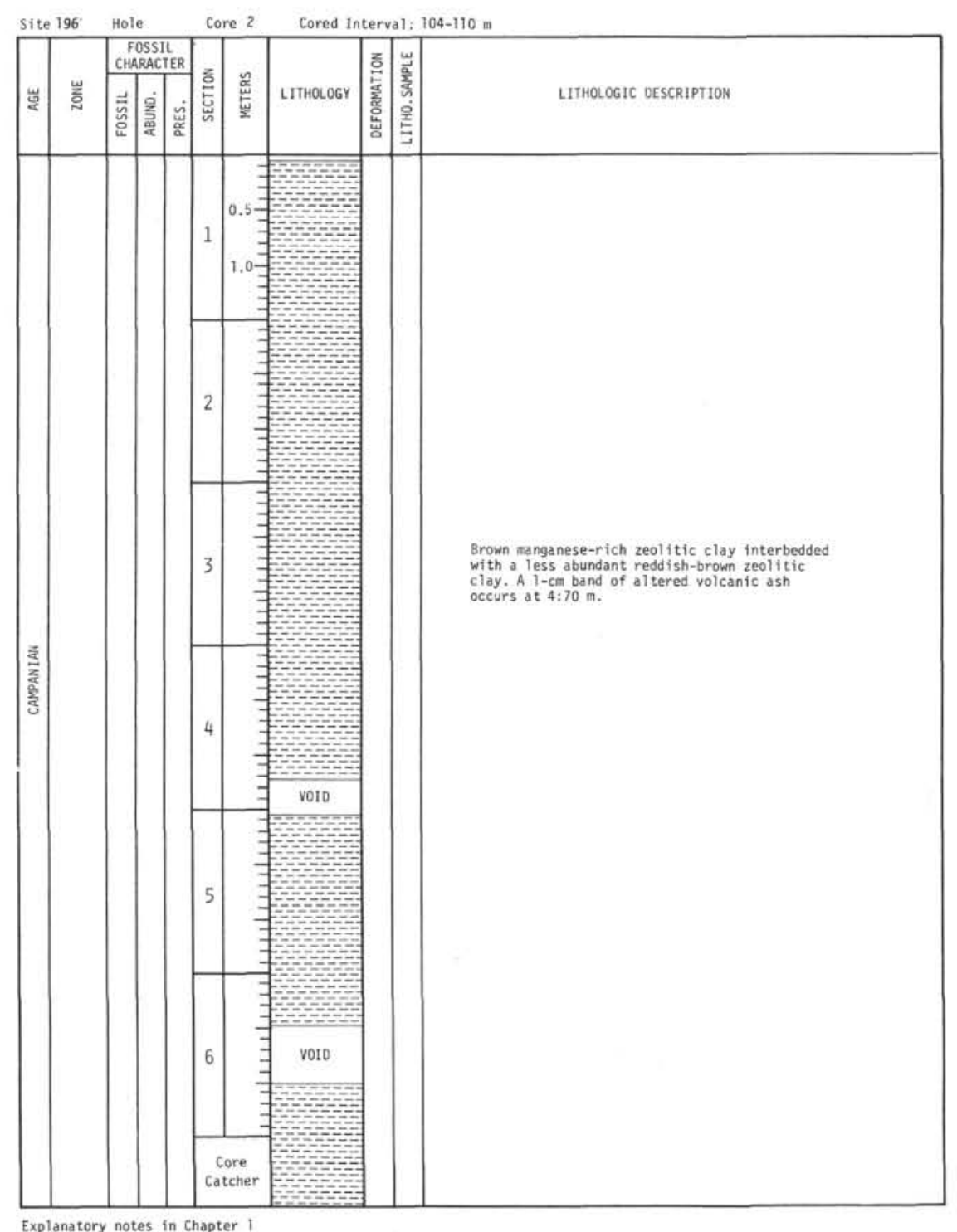




\begin{tabular}{|c|c|c|c|c|c|c|c|}
\hline \multicolumn{2}{|c|}{ Site 196} & \multicolumn{3}{|c|}{ Hole Core 3} & \multicolumn{3}{|c|}{ Cored Interval: $197-203 \mathrm{~m}$} \\
\hline 峞 & 粉 & 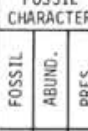 & Titer & 总 & เттно.06Y & 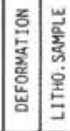 & LITHOLOGIC OESCRIPTION \\
\hline 点 & 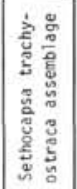 & & 1 & $1.0 .5=$ & 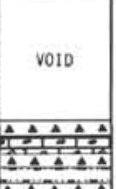 & & 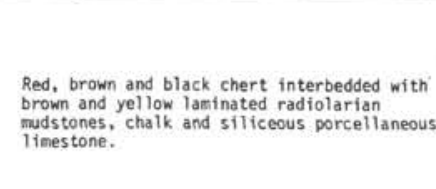 \\
\hline
\end{tabular}

Explanatory notes in chapter

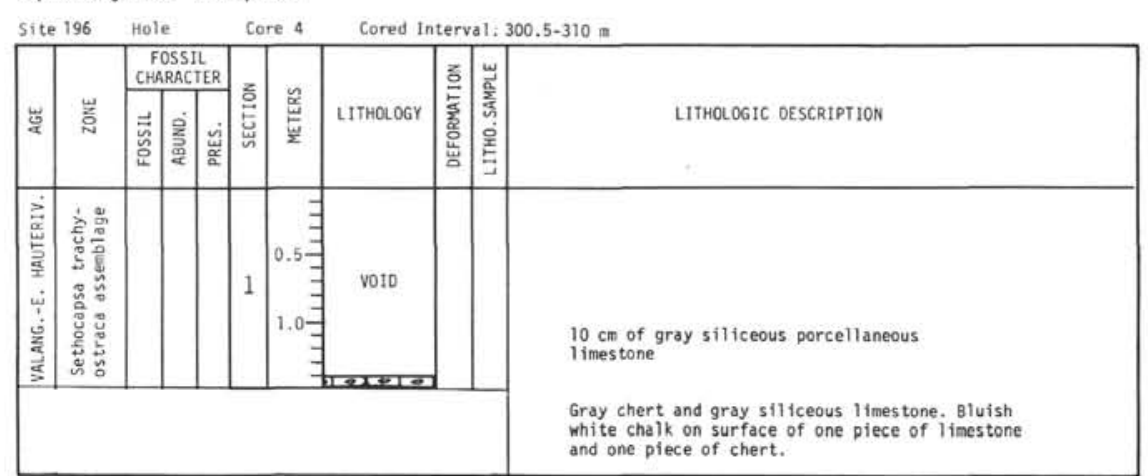

Explanatory notes in chapter 1

Site 196 Hole Core 5 Cored Interval: $360.5-370 \mathrm{~m}$

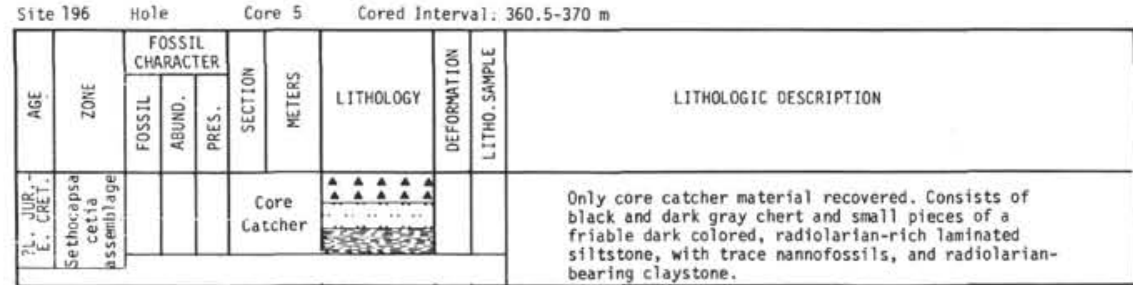

Explanatory notes in Chapter 1 


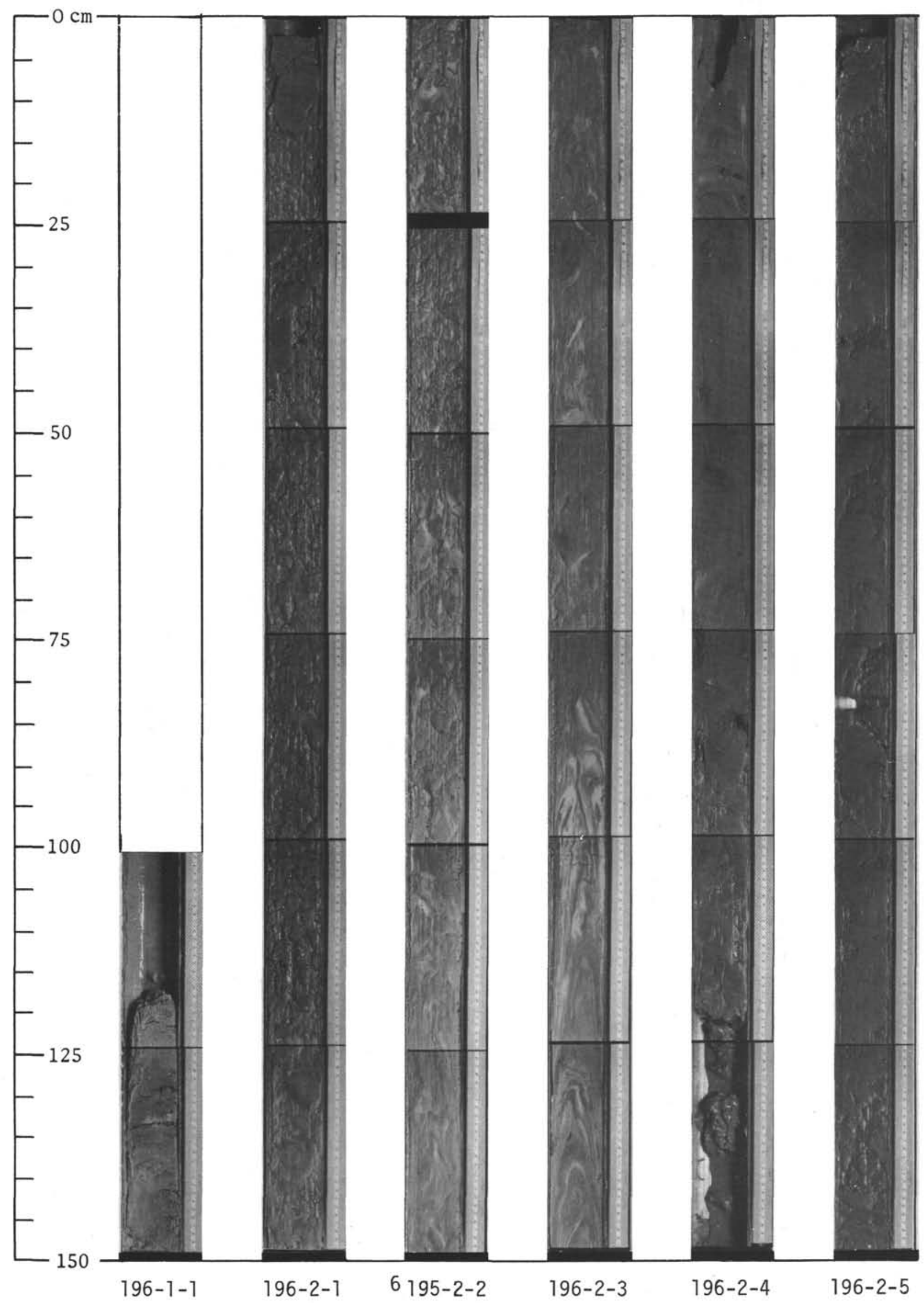




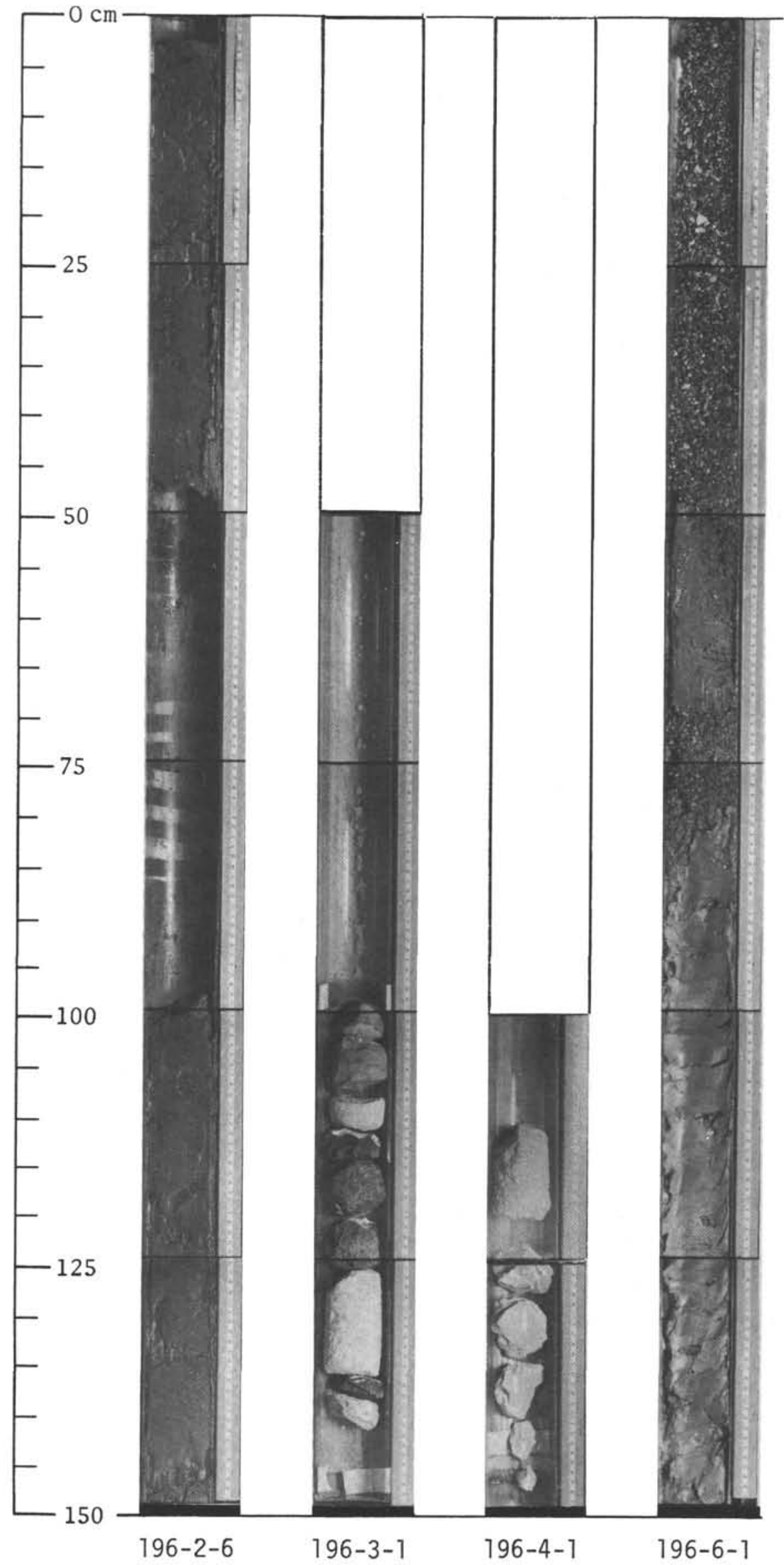

